\title{
A White Spot Disease - like syndrome in the Pacific Blue Shrimp (Litopenaeus stylirostris) as a form of bacterial shell disease
}

\author{
GOARANT Cyrille*, BRIZARD Raphaël, MARTEAU Anne-Laure
}

Laboratoire de Recherche Aquacole IFREMER en Nouvelle-Calédonie, Station d'Aquaculture de Saint Vincent, BP 2059, 98845 Nouméa Cedex, New Caledonia (South Pacific)

*: Corresponding author : cgoarant@ifremer.fr, Phone 6872851 71, Fax 687287857

\begin{abstract}
:
In May 1997, some white lesions evoking the white spot syndrome disease were observed in Litopenaeus stylirostris broodstock in New Caledonia. The occurrence of these lesions was neither associated with mortality, nor with histological evidence of White Spot Syndrome Baculovirus (WSBV). The evidence suggests that these lesions result from a form of bacterial disease and are associated with an increased bacterial flora on the outer surface of the cuticle, as well as an increased incidence throughout the molt cycle. A microscopic observation of these lesions allows them to be differentiated from WSBV-associated lesions.
\end{abstract}




\section{Introduction :}

There have been number of cases reporting the presence of white spot lesions on shrimp shells (AQUACOP, 1984 ; Lee et al., 1996 ; Limsuwan, 1997). Most of these cases were associated with mortalities caused by viruses of the White Spot Syndrome Baculovirus complex (Takahashi et al., 1994 ; Chou et al., 1995 ; Wang et al., 1995), that cause severe losses in shrimp farms, the major gross sign in diseased shrimp being the presence of white spots on the cuticle. Yet in some cases, there is neither evidence of viral aetiology, nor mortality, though susceptible species are concerned.

In May 1997, some white spot lesions evoking the White Spot Disease were observed in reared Pacific blue shrimp Litopenaeus stylirostris broodstock in New Caledonia. The occurrence of these lesions was associated with neither mortality, nor histological evidence of White Spot Syndrome Baculovirus (WSBV), though L. stylirostris is a sensitive species to WSBV infection (Lightner et al., 1998). Because of the external aspect of the lesions, it was hypothesised that they could be a form of bacterial shell disease (Cook and Lofton, 1973). The aim of this study was to investigate this hypothesis, and to investigate if these lesions could be routes of entry of other bacterial pathogens. Bacterial examination of both the cuticular epibiotic flora and the haemolymph flora was carried out using conventional methods.

\section{Material and methods :}

$\underline{\text { Animals, lesions grading and molt staging : }}$

Juvenile Litopenaeus stylirostris from our collection fixed in Davidson's (1995-1997) were dissected. Direct and microscopic examination for the presence of white lesions on the cuticle was carried out. Broodstock Litopenaeus stylirostris originating from the «Ecloserie du Nord » Hatchery (Koné, New Caledonia), where the lesions were observed for the first time, were either examined directly at the hatchery laboratory (direct and microscopic examination) 
or brought alive to our laboratory for a long term observation. The animals were held in a two cubic metre concrete pond with periodic water exchange (37 ppt salinity), progressive water heating $\left(25^{\circ} \mathrm{C}\right.$ to $\left.30^{\circ} \mathrm{C}\right)$, and fed ad libitum with a complete commercial diet. These animals were periodically examined for molt stage and lesion grading. Some of them were examined bacteriologically and discarded.

Lesions were graded from 0 to 3 depending upon their abundance and diameter, after microscopic examination of the carapace (magnification: X25). Dissected shells were also observed under the light microscope for the general appearance of the lesion. Molt stages of the examined shrimp were determined according to Drach (1939) and Chan et al. (1988).

\section{Bacterial media, epibiotic and haemolymph bacterial flora :}

TCBS agar (for presumptive Vibrionaceae flora) and Marine Agar 2216 (for total heterotrophic flora) both from Difco laboratories were used for this study. A colloidal suspension of chitin was added to the Marine Agar before use (Hansen and Sørheim, 1991). The epibiotic bacterial flora were collected by rubbing a half square centimetre of carapace shell, after rinsing it with sterile seawater. The epibiotic flora was streaked directly onto agar plates. After rinsing the shrimp with sterile seawater, haemolymph was withdrawn from the ventral sinus using a sterile tuberculin syringe and needle. One drop of haemolymph was placed aseptically onto the agar plates and spread with a sterile loop. Colony Forming Units were counted after 24 hours (for TCBS) to five days (for Marine Agar) incubation at $30^{\circ} \mathrm{C}$. Results were analysed by using Stat View ${ }^{\circledR}$ software.

\section{Results :}

The lesions induce a fragility through thinning the cuticle. The microscopic examination shows that the lesions seem to spread from an initial wound. The more extensive lesions showed a small melanised centre (Figure 1b, arrows), evoking the bacterial shell disease 
(Cook and Lofton, 1973). The same lesions were frequently observed on collection animals fixed in Davidson's in the years 1995 to 1997. Animals originating from growout ponds had similar but frequently smaller lesions. Broodstock animals kept at the laboratory showed an increase in mean lesion grade when heating seawater from $25^{\circ} \mathrm{C}$ to $30^{\circ} \mathrm{C}(\mathrm{F}=10.32 ; \mathrm{p}<0.01)$ and through the molt cycle (Figure 2). In late D stage animals, the dissection allowed to show that the lesions were absent from the future cuticle. Males and females had similar lesions $(\mathrm{t}=0.536 ; \mathrm{p}=0.59)$. The study also demonstrated a positive correlation between lesion grade and cuticular total heterotrophic flora $(\mathrm{F}=17.411 ; \mathrm{p}<0,001)$. Presumed Vibrio levels (isolated on TCBS agar) were low in haemolymph and found only in affected animals. Chitinoclastic bacteria, as demonstrated by a halo surrounding the colony on chitin marine agar were present on almost all cuticles and were not significantly related to the grade of the lesions. They were also more abundant in haemolymph of affected animals $(\mathrm{p}=0.17)$.

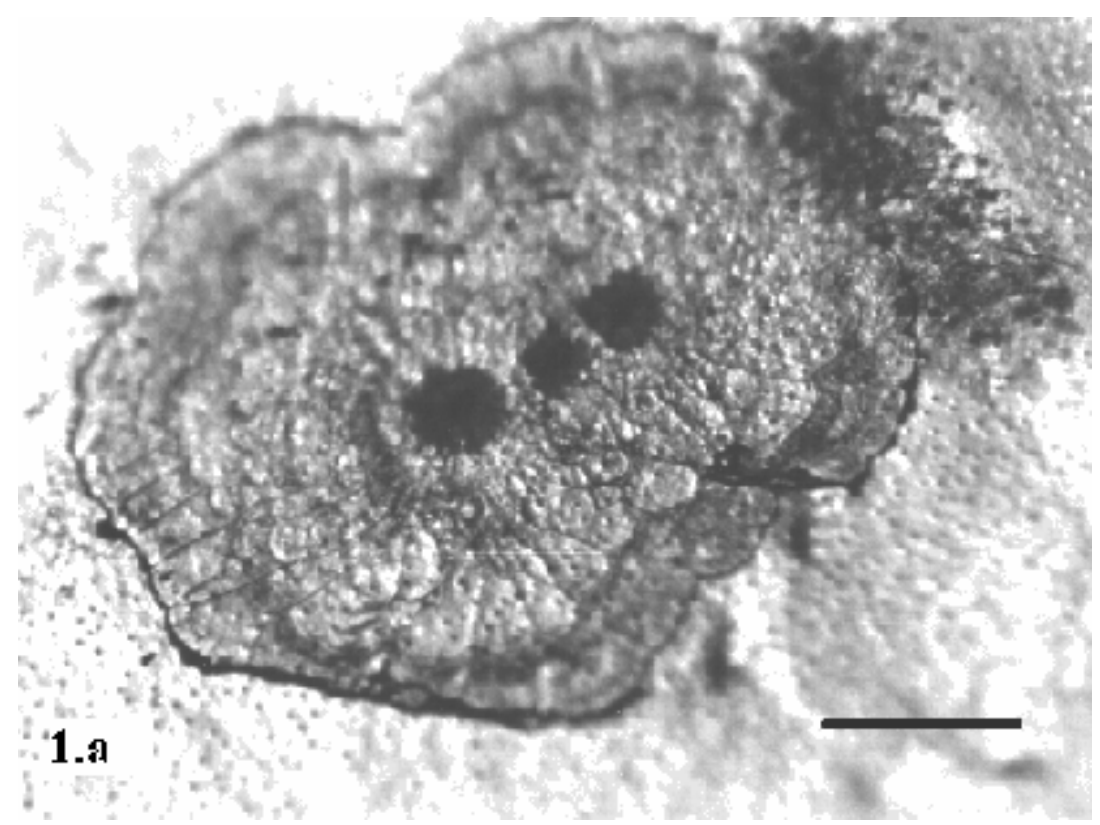




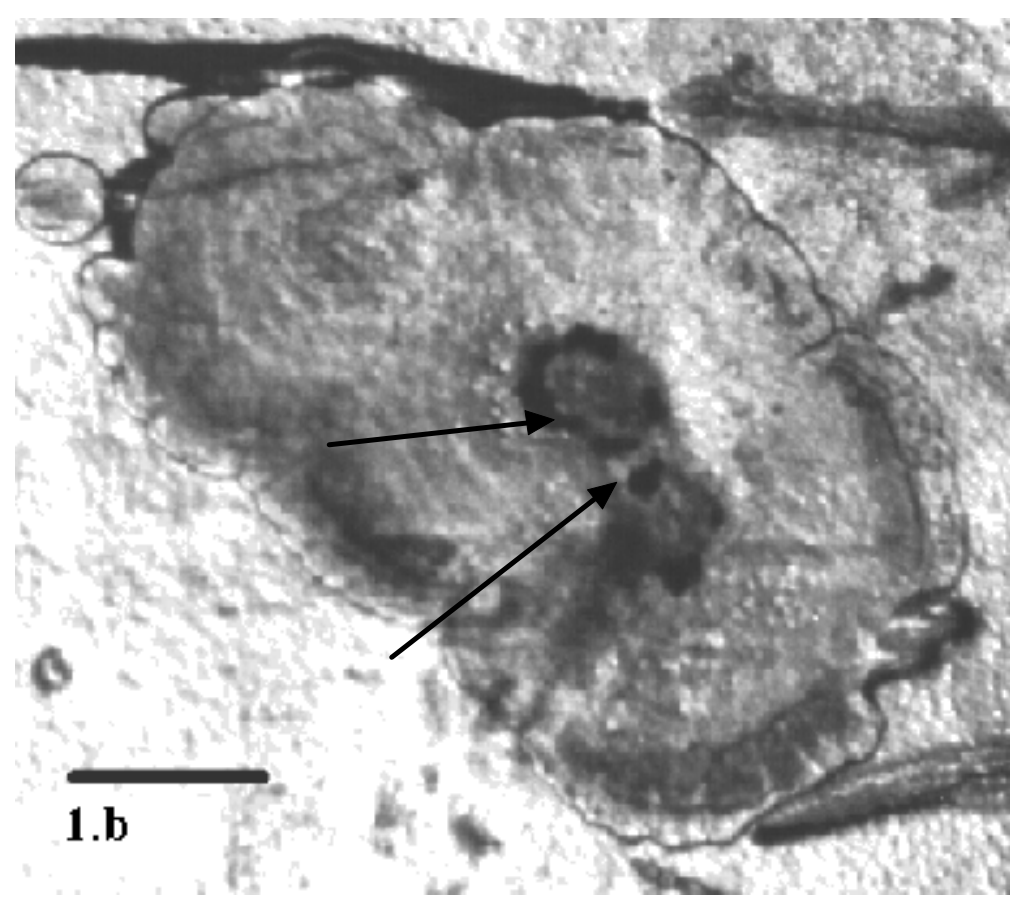

Figure 1: Microscopic view of the white spot lesions observed on cuticles of Litopenaeus stylirostris broodstock (fig 1.a). Some show a small melanisation area (fig 1.b; arrows). Bars indicate $1.0 \mathrm{~mm}$. Magnification X 50

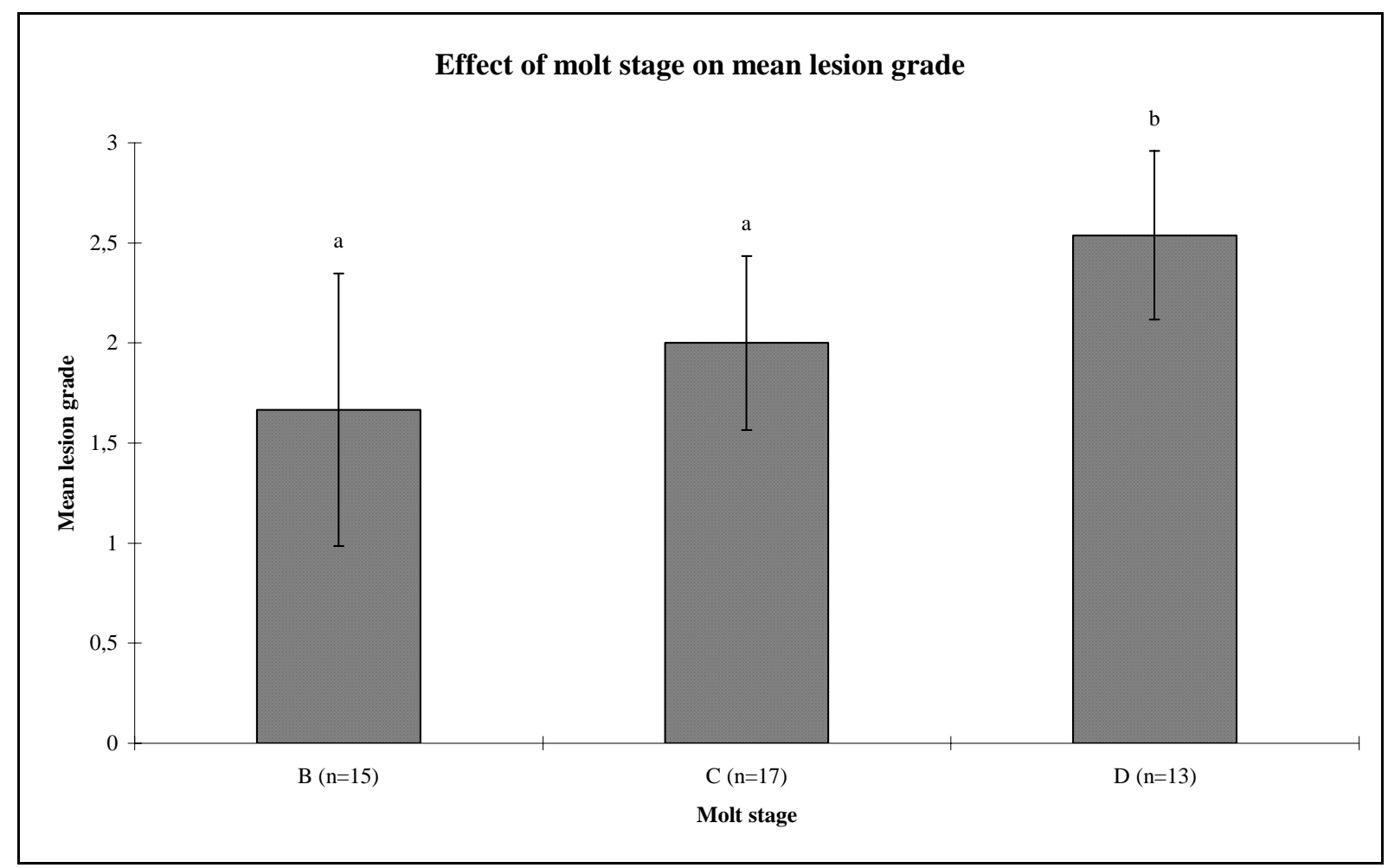

Figure 2 : Effect of molt stage on mean white spot grade. Bars represent 95\% confidence intervals. Bars showing the same letter do not differ significantly. ( $\mathrm{n}=$ indicates the number of animals from each molt stage). 


\section{Discussion :}

The presence of a more extensive epibiotic bacterial flora on diseased cuticles demonstrates that these lesions are external. There was an increased prevalence of the lesions through the molt cycle as shown by the mean lesion grades, Furthermore, the underlying future cuticle of late D stage animals were unaffected. It demonstrates that the molt process allows the disappearance of the lesions. Broodstock animals had the largest lesions, probably because they molt less frequently, their cuticle being therefore exposed for longer periods of time, as hypothesised by Getchell (1989) for shell disease in crabs. An increase in prevalence was observed when the water temperature in the maturation facilities at the « Ecloserie du Nord » Hatchery was increased to $30^{\circ} \mathrm{C}$ as to induce maturation in broodstock females. This observation was confirmed in the laboratory and also demonstrated that this phenomenon was not related to the sex of the animals. Sindermann (1988), reporting on the « shell disease » in the blue crab (Callinectes sapidus) stated that this disease increases with temperature. These elements allow to hypothesise that the lesions mentioned in this study correspond to a form of bacterial shell disease. A microscopic observation permit the differentiation of the lesions caused by this presumed bacterial shell disease and the WSBV-associated lesions: in the shell disease, the lesion is external, results in a thinning and an increased fragility of the cuticle and sometimes melanisation of the underlying tissues (Cook and Lofton, 1973 ; Sinderman, 1988 ; Getchell, 1989), whereas in the WSBV-associated lesions, the lesions are calcium deposits on the inner surface of the cuticle (Lightner, 1996), and no melanisation occurs in the underlying tissues.

\section{Conclusion.}

The observations described in this study seem to demonstrate that the white spot lesions observed on Litopenaeus stylirostris broodstock are a form of localised bacterial shell disease, which rarely results in perforation of the cuticle. When the cuticle is punched, a melanised 
zone appears, and the lesion looks like a traditional shell disease named «black spot» or «brown spot disease » (Lightner, 1988). AQUACOP (1984) reported a " white shell spot disease » in Litopenaeus stylirostris, L. vannamei and Fenneropenaeus merguiensis. These lesions were most often seen in female broodstock in maturation facilities, when increasing water temperature, and were not associated with any mortality (J. Patrois, IFREMER-COP, BP 7004 Tahiti, French Polynesia, pers. com.). These lesions were most probably identical to the lesions described in this study.

Acknowledgements: This work was partly supported by grants from the North and South Provinces of New Caledonia. 


\section{References:}

AQUACOP, 1984. Review of ten years of experimental Penaeid shrimp culture in Tahiti and New Caledonia (South Pacific). J. World Maric. Soc. 15: 73-91.

Chan, S.M. ; Rankin, S.M. ; Keeley, L.L., 1988. Characterization of the molt stages in Penaeus vannamei: setogenesis and hemolymph levels of total protein, ecdysteroids and glucose. Biol. Bull. 175: 185-192.

Chou HY, Huang CY, Wang CH, Lo C-F., 1995. Pathogenicity of a baculovirus infection causing white spot syndrome in cultured penaeid shrimp in Taiwan. Dis. Aquat. Org. 23: 165173.

Cook, D. W. ; Lofton, S. R., 1973. Chitinoclastic bacteria associated with shell disease in Penaeus shrimp and the blue crab (Callinectes sapidus). J. Wildl. Dis. 9: 154-159.

Drach, P., 1939. Mue et cycle d'intermue chez les Crustacés Décapodes. Annales de l’Institut Océanographique de Paris N.S. 19: 103-391.

Getchell RG., 1989. Bacterial shell disease in Crustaceans : a review. J. Shellfish Res. 8: 1-6.

Hansen, G.H. ; Sørheim, R., 1991. Improved method for phenotypical characterization of marine bacteria. J. Microbiol. Methods. 13: 231-241.

Lee KK, Yu S-R, Chen F-R, Yang T-I, Liu P-C., 1996. Virulence of Vibrio alginolyticus isolated from diseased Tiger Prawn, Penaeus monodon. Curr. Microbiol. 32(4):229-31. 
Lightner, D.V., 1988. Bacterial shell (brown spot) disease. In: Developments in Aquaculture and Fisheries Science, vol. 17. Disease diagnosis and control in North American marine aquaculture.. C.J. Sindermann and D.V. Lightner, editors. Elsevier, Amsterdam. pp.48-51.

Lightner, D.V., 1996. White Spot Syndrome Baculovirus Complex. In: D.V. Lightner, editor. A Handbook of Shrimp Pathology and Diagnostic Procedures for Disease of Cultured Penaeid Shrimp. World Aquaculture Society, Baton Rouge, Louisiana, USA.

Lightner DV, Hasson KW, White BL, Redman RM., 1998. Experimental infection of western hemisphere Penaeid shrimp with asian white spot syndrome virus and asian yellow head virus. J. Aquat. Anim. Health 10:271-81.

Limsuwan C., 1997. What kind of white spot kills shrimp ? AAHRI Newsletter 6: 4-5.

Sinderman, C.J., 1988. Shell disease. in Developments in aquaculture and fisheries science, vol. 17. Disease diagnosis and control in North American marine aquaculture. C.J. Sindermann and D.V. Lightner, editors. Elsevier, Amsterdam. pp.194-196.

Takahashi Y, Itami T, Kondo M, Maeda M, Fujii R, Tomonaga S, Supamattaya K, Boonyaratpalin S., 1994. Electron microscopic evidence of bacilliform virus infection in Kuruma shrimp (Penaeus japonicus). Fish Pathol. 29: 121-125.

Wang CH, Lo C-F, Leu J-H, Chou C-M, Yeh P-Y, Chou H-Y, Tung M-C, Chang C-F, Su MS, Kou G-H., 1995. Purification and genomic analysis of baculovirus associated with white spot syndrome (WSBV) of Penaeus monodon. Dis. Aquat. Org. 23: 239-242. 